Dossier Anthropology on Latin America and the Caribbean today:

New Theoretical and Methodological Challenges

\title{
What was Research for the Peasants of Córdoba? Participation in the Early Years of Participatory Action Research
}

Joanne Rappaport ${ }^{1}$

'Georgetown University, Department of Spanish and Portuguese, Washington DC, USA

\begin{abstract}
Reflections on participatory and collaborative research commonly neglect to pay attention to the fact that for community researchers, investigation into their own realities frequently takes forms very different from those of academic scholars. They may use methods that are more explicitly intuitive and may depart from approaches that involve the rigorous collection and systematization of data. This paper explores what research might have meant to the Caribbean peasants of the early 1970 with whom Colombian sociologist Orlando Fals Borda developed his approach to what is today called participatory action research. In particular, it focuses on the field notes of Alfonso Salgado Martínez, a leader of the National Association of Peasant Users-Sincelejo Line (ANUC, Asociación Nacional de Usuarios Campesinos-Línea Sincelejo), juxtaposing them to his published work, both read in comparison to Fals Borda's own notes and writings.
\end{abstract}

Key words: Participatory-Action Research, Orlando Fals Borda, Colombia. 


\section{¿Qué fue la investigación para los Campesinos de Córdoba? Participación en los primeros años de la investigación-acción participativa}

\section{Resumen}

Las reflexiones sobre la investigación participativa y colaborativa suelen dejar de prestar atención al hecho de que, para los investigadores comunitarios, la investigación de sus propias realidades suele adoptar formas muy diferentes a las de los académicos. Pueden utilizar métodos que son explícitamente intuitivos y pueden apartarse de enfoques que implican la recopilación y sistematización rigurosa de datos. Este artículo explora lo que la investigación pudo haber significado para los campesinos caribeños de principios de la década de 1970 con quienes el sociólogo colombiano Orlando Fals Borda desarrolló su enfoque de lo que hoy se llama investigación-acción participativa. En particular, se centra en las notas de campo de Alfonso Salgado Martínez, líder de la Asociación Nacional de Usuarios Campesinos-Línea Sincelejo (ANUC, Asociación Nacional de Usuarios Campesinos-Línea Sincelejo), yuxtaponiéndolas a su trabajo publicado, ambos leídos en comparación a las notas y escritos del propio Fals Borda.

Palabras claves: Investigación-Acción Participativa, Orlando Fals Borda, Colombia.

\section{O que era pesquisa para os Camponeses de Córdoba? Participação nos primeiros anos da pesquisa-ação participativa}

\section{Resumo}

As reflexões sobre a pesquisa participativa e colaborativa comumente negligenciam prestar atenção ao fato de que, para os pesquisadores comunitários, a pesquisa sobre suas próprias realidades frequentemente assume formas muito diferentes daquelas dos acadêmicos. Eles podem usar métodos que são mais explicitamente intuitivos e podem partir de abordagens que envolvem a coleta e sistematização rigorosa de dados. Este artigo explora o que a pesquisa pode ter significado para os camponeses caribenhos do início dos anos 1970, com quem o sociólogo colombiano Orlando Fals Borda desenvolveu sua abordagem que hoje é chamada de pesquisa-ação participativa. Em particular, concentra-se nas notas de campo de Alfonso Salgado Martínez, líder da Associação Nacional de Usuários Camponeses-Linha Sincelejo (ANUC, Asociación Nacional de Usuarios Campesinos-Línea Sincelejo), justapondo-as a seu trabalho publicado, ambos lidos em comparação às próprias notas e escritos de Fals Borda.

Palabras clave: Investigación-Acción Participativa, Orlando Fals Borda, Colombia. 


\title{
What was Research for the Peasants of Córdoba? Participation in the Early Years of Participatory Action Research
}

\author{
Joanne Rappaport
}

One of the strands of what is known today as participatory action research (PAR) was conceived by Orlando Fals Borda and a network of researchers, La Rosca de Investigación y Acción Social (Circle of Research and Social Action), which functioned in various parts of Colombia in the early 1970s. Their objective was to support grassroots struggles through the development of a research methodology aimed at forging horizontal relationships between those who traditionally conduct research and those who are traditionally the objects of investigation, thereby overturning the distinction between object and subject, and making the results of historical research available in accessible formats to popular movements (Bonilla et. al., 1972; Fals Borda, 1985, 2007). Working in the Colombian departments of Cauca, Córdoba, Tolima, Sucre, and Valle del Cauca with Afrocolombian, Indigenous, and peasant populations, members of La Rosca collaborated with a series of organizations, the most well-known being the Asociación Nacional de Usuarios Campesinos-ANUC Línea Sincelejo (National Association of Peasant Users-Sincelejo Line) and the Consejo Regional Indígena del Cauca-CRIC (Regional Indigenous Council of Cauca), to unearth histories of popular struggles that could serve as examples for rural activists bent on occupying haciendas and engaging in mass mobilizations. Fals Borda's collaboration with ANUC in the department of Córdoba lasted for three years, from 1972 to late 1974 (Parra Escobar, 1983). ${ }^{1}$

Writing a history of PAR poses a major challenge to historians of social science. While in many cases we have access to the products of early efforts at participatory research and we can piece together the activities that fueled the process, it is difficult to determine the extent to which the grass roots were active participants in these projects: Did the rank and file of the organizations with which PAR researchers collaborated engage in the collection and analysis of information, were they mere informants, or were there intermediate positions on the participatory spectrum? It is not easy to answer this question, given that our primary sources are the materials these projects produced (many times written by the external researchers), retrospective analyses that are generally celebratory in nature, and the forty-year-old memories of the originators of these methodologies. This is the case for Fals Borda's experiment in participation, which he called "action research" (but I will call "PAR"). In this article, I will explore the nature of peasant participation in action research and will argue that to answer this question we must take into account the shifting meanings ascribed to research in participatory and collaborative contexts.

I began to work with Fals Borda's personal papers more than a decade ago, with the intention of reconstructing the story of the Fundación del Caribe (Caribbean Foundation, hereafter, the Fundación), the La Rosca research group founded in the coastal city of Montería by Fals Borda in 1972. ${ }^{2}$ The Fundación's membership was largely

\footnotetext{
1 Spanish surnames are a composite of the patronymic (in this case, Fals) and the matronymic (Borda). Individuals are identified either by a combination of the two or the patronymic (Fals), never by the matronymic alone: Fals Borda or Fals, but never Borda.

2 I worked primarily in two archives, as well as conducting interviews with the surviving Fundación members and their allies; almost none of the peasant leaders who worked with the Fundación are still living. The Archivo Central e Histórico de la Universidad Nacional de Colombia in Bogotá (henceforth, ACHUNC/B) contains the vast majority of Fals Borda's personal papers, which I cite by caja, carpeta, and folio. The Centro de Documentación Regional "Orlando Fals Borda," Banco de la República, Montería (henceforth, CDRBR/M) contains his personal papers arising out of his collaboration with ANUC on the Caribbean Coast, which was merged with the archive of the now-defunct Fundación del Caribe; my references to this archive cite the document number and when relevant, I also cite the folio; in those cases in which a multi-page document has been given a single folio number, I also cite the page.
} 
made up of young urban activists (mostly men) of popular extraction, many of whom had not received training in the social sciences, although a few had university degrees in other fields. The Fundación operated in various cities on the Atlantic Coast, including Barranquilla, Montería, and Sincelejo, conducting historical research, producing educational materials, and collaborating politically with ANUC. I was particularly interested in how peasants participated in its research projects. From the mid-19gos to the early 2000 s I had forged a collaborative relationship with members of CRIC and with the Asociación de Cabildos Indígenas del Norte del Cauca-ACIN (Association of Indigenous Councils of Northern Cauca) [Rappaport 2008 (2005), 2015]), working with research teams and leading a series of training workshops with Indigenous activists studying the nature of ethnic politics and the construction by the Indigenous movement of culturalist discourses. Many, but not all, of my co-researchers were university trained, although not necessarily in qualitative research methods. Our research topics coincided with their activist obligations and objectives. Thus, they had ample opportunity to conduct investigations while going about their everyday work life, which consisted in part in the facilitation of workshops and focus groups with local communities and teachers. Their research techniques were largely collective, although one of the two teams engaged in recording formal interviews. In one of the CRIC teams, we co-authored the results of our research (Bolaños, Ramos, Rappaport, and Miñana, 2004), while in the other team, we each wrote our pieces individually, the research group providing extensive support to those who had less writing experience (Rappaport 2005b); the CRIC activists also prepared popular educational materials based on their research. In the case of ACIN, each of the participants published an article in Señas, the magazine of the Casa de Pensamiento, which at the time was the research arm of the organization (Caro and Valencia 2013; Pequí, 2013; Velasco, 2013). As an external scholar I confined my activities to investigation and did not participate as an activist, although I contributed in an educational capacity to the organizations with which I had agreed to collaborate, facilitating workshops and participating in other adult educational venues.

I naively presupposed that Fals's experience on the Atlantic Coast would be similar to my work in Cauca. To the contrary, I discovered that on the one hand, Fals and his colleagues were active participants in ANUC and never confined their activities exclusively to research, in contrast to collaborative researchers, who frequently maintain a distance from the political workings of the organization. On the other hand, unlike today's collaborative and participatory teams, who frequently count with the support of community researchers with a modicum of formal training, there were few campesinos-Spanish for "peasant"-whom the Fundación deemed as sufficiently trained to conduct research. Fundación members observed in their reports that collective research strategies were hampered by campesinos' limited access to literacy, which the Fundación deemed essential to the process. Moreover, they thought that the dual demands of agricultural work and political activism would restrict the time that peasants could dedicate to investigation (CDRBR/M, 0642, fol. 3375). ANUC's departmental leadership and local activists certainly had a say in setting the research agenda and selecting the topics to be studied. However, the Fundación's participation in the peasant organization tended to privilege political work over research, so that in the end, because research was given a lower priority, the Fundación ended up defining research objectives on the ground (Zamosc, 1986a: 29). Notwithstanding these limitations, Fals was able to foster the development of horizonal research relationships with the municipal leadership of ANUC and with some peasant associations in localities, in particular through the process of preparing a series of historical comics documenting the peasant struggles of the past (Chalarka, 1985); campesinos were involved in the selection, narration, and evaluation of these historical narratives (Rappaport 2020: chap. 3) and once they were published, participated in their analysis at workshops and other educational events (Ibid.: chap. 4). Notwithstanding these accomplishments, the brief duration of the ANUC-Fundación del Caribe collaboration, which was cut short at the end of 1974 by government repression and factionalism on the left (Parra Escobar, 1983; Zamosc, 1986b), did not result in the creation of a corps of peasant researchers. 
Nonetheless, that outcome was one of Fals Borda's ultimate goals. In 1974, he and Augusto Libreros, one of the co-founders of La Rosca, prepared a mimeographed manual for would-be peasant researchers, titled "Cuestiones de metodología" ("Questions of Methodology"), which outlines a basic methodology for peasant researchers (ACHUNC/B, caja 49, carpeta 3, fols. 177-268; Fals Borda, 1978: 48). Unlike later collaborative approaches that emerged in Cauca from among the successors to La Rosca, using methodologies that privileged the creation of culturally specific conceptual vehicles for interpreting and reporting research results (Vasco, Dagua y Aranda 1993) — which I gloss as "co-theorization" (Rappaport, 2005a)—Fals and Libreros, who were working at the dawn of collaborative research, fostered the use of scientific techniques: "Here, we apply wellknown rules of scientific observation, such as analysis, deduction and induction, measurement, and care and equilibrium in the collection of evidence" (ACHUNC/B, caja 49, carpeta 3, fol. 214). The manual took readers step by step through the process of collecting and analyzing information.

Fals and Libreros hoped that one day in the distant future, peasant researchers would ply their craft without outside assistance, but until then, they focused more pointedly on how the intervention of external researchers could promote the political objectives of the social movements with which they were affilliated: "The uses of history should coincide with the needs ... of the present, instead of being limited to simple and interesting stories of the past. The 'narrator' can assume the role of a social critic or share organizational demands during the narration or at the end of the pamphlet" (ACHUNC/B, caja 49, carpeta 3, fols. 259-259v). In effect, then, they saw narrators as co-researchers or co-analysts, to some extent blurring the distinction between narrator and informant. Notwithstanding, the testimonies recorded by the Fundación researchers were frequently recounted in collective settings, where the audience and the narrators could engage in discussion and interpretation. At all phases of the research - collection of evidence, preparation of written materials, and their use in workshopscommunity members were encouraged to take a critical stance on the narratives they were hearing and to use history as a window into their own experiences, although they were provided with critical analyses by the narrators pictured in the comics, who were identifiable local people; the narratives featured in the graphic histories were, nonetheless, composites of information that came from interviews with various respondents, thus complicating whose voice we hear in these publications. The Fundación appears to have limited peasant research to the communal analysis of historical narratives whose collection and dissemination was controlled by the external researchers.

The Centro Popular de Estudios (People's Studies Center), a peasant-run research organization, was set up as a counterpart to the Fundación del Caribe. As the copyright page of a prose history of the struggle for the mangroves in San Bernardo del Viento, Córdoba, explains: "The Centro Popular de Estudios is a non-profit entity created to study the historical, economic, social, and cultural realities of the Atlantic Coast; and to systematize this knowledge and disseminate it, particularly in popular sectors, in order to make more effective their efforts at self-determination" (CDRBR/M, 1918). Several of the ANUC leaders closest to Fals Borda were affiliated with the Centro Popular de Estudios, which issued a series of pamphlets, including a guide for peasants on how to run a cursillo, or training workshop (Centro Popular de Estudios, 1972), and a reading primer for children (Centro Popular de Estudios, 1974), illustrated by the same artist, Ulianov Chalarka, who drew the Fundación's graphic histories. All of the Centro's publications were anonymously authored; presumably they were products of working groups combining peasants and external researchers, although it is not clear in what capacity the peasants served. Fals retained a manuscript copy of the cursillo manual in his personal archive, filled with corrections in his handwriting, indicating that it was a collective effort (CDRBR/M, 2180).

Notwithstanding the existence of the Centro Popular de Estudios, I found only scant evidence that Fals mentored many would-be campesino researchers. I uncovered some documentation by peasant leaders of their activities in rural communities, texts that fuse a quasi-ethnographic description of the social context with a report of their political activities. The most extensive piece of campesino writing in the archive is 
the autobiography of Moisés Banquett, a municipal leader of ANUC who shared his life history with Fals a few years after the demise of the Fundación del Caribe (CDRBR/M, 1041-1058; Pernett, 2015). ${ }^{3}$ In his memoirs, Banquett recalls his introduction to Marxist texts in the cursillos he attended, indicating that he drew on the political education he received from ANUC to interpret his personal experience. But on the whole, I found very few other examples of peasant research, if we understand research to be the compilation and analysis of information. One of the exceptions to this rule is a brief field diary belonging to ANUC leader Alfonso Salgado Martínez, a prominent regional activist who later published a pamphlet on political economy with the Centro Popular de Estudios under the pseudonym "Alsal Martínez" (Martínez, 1973). While Salgado's notes span but a handful of pages, they can be juxtaposed to his published work, thus giving us an idea of what it meant to be a campesino researcher in the 1970 .

Alfonso Salgado's approach to research differed considerably from that of Fals and the members of the Fundación del Caribe, insofar as it did not involve the systematic collection and analysis of information but instead followed a more intuitive process of systematizing personal experience, followed by a process of critical reflection of the sort that occurred in training workshops, all of which was meant to contribute to a political project. Salgado combined his life experience, his political training in ANUC, and his informal conversations with other peasants. He did not collect his evidence systematically-these are the only notes of his we have access to-nor is the information he recorded explicitly analyzed in a written product. Instead, his research appears to have been a tool for refining his political discourse in order to make it more effective. One might say that Salgado's approach to research was not the collection of information, but an act of the imagination in which the sum total of his experiences enabled him to project possibilities on the political stage.

Salgado's experience has a great deal to tell academics about how our partners approach the collaborative research experience. While our academic toolkit certainly enables us to make a significant contribution to a collaborative project, academic rigor operates in a kind of synergy with what is frequently an entirely different approach to collecting and processing information by our counterparts. I suspect that Fals Borda comprehended this difference, which is why he set aside his academic writing until well after his collaboration with ANUC ended, focusing instead on an interlinked series of products in a range of media that supplied the foundations of an adult-educational program consisting of cursillos, which fostered the continuing participation of peasants in the interpretation of their historical legacy and its translation into political action. He also left space open for ANUC allies like Alfonso Salgado to approach research on their own terms. While perhaps Fals and his associates ascribed too much importance to scientific methodologies and to literacy, and notwithstanding the greater emphasis they placed on activism over research — thereby reducing their methodology's activist potential - the fact that they were ultimately unable to achieve their goals does not diminish the significance of Fals' work for those of us who came after.

\section{Alfonso Salgado's Field Notes}

I will focus on Alfonso Salgado's field report recording the life histories of a series of rural laborers in Tuchín de Aguas Vivas, Córdoba (CDRBR/M, 0211). He collected this testimony in the course of conversations with Indigenous migrants originally from Tuchín, a hamlet belonging to the Zenú community of San Andres de Sotavento, a place known for its basketry and straw hats (as well as for the itinerant coffee-peddlers in coastal cities). Salgado himself was originally from Canalete, located to the west of Montería, the modern-day capital

3 The text remains unpublished because Banquett disappeared and there is no one from whom to solicit permission for publication. A similar memoir, authored by Jesús María Pérez, an ANUC leader in Sucre, was published with his collaboration (Pérez, 2010) and his personal archive was uploaded to the Archivo Virtual de los Derechos Humanos of the Centro Nacional de Memoria Histórica <http://archivodelosddhh.gov.co/saia_release1/ws_client_oim/menu_ usuario.php> Accessed 2 April 2021. 
of the department of Córdoba, and was one of the small number of peasant leaders who worked closely with Fals Borda and the Fundación del Caribe. I do not know if his report was compiled at Fals Borda's request, or if instead, it was commissioned by ANUC; it may have also been a personal project of Salgado's, conducted while he pursued his political obligations.

Salgado's own life experience parallels that of his respondents: "I am a man who was a day-worker, a lumberjack, I've done everything there is to do in the countryside. So I know about all those professions. I not only lumbered alone, but with large crews, using machetes and all that. I know what life is like in the countryside and I'm the sort who remembers everything, I watch everything that happens" (Parra Escobar, 1983: 146). We can see what he saw and remembered in his field notes. He conducted his interviews in April, 1973, with three elderly respondents, two of whose narratives I highlight here. Writing in an unschooled hand, with no accent marks, uneven capitalization, and questionable punctuation but bursting with reported speech and narrated in the first person, he depicts his respondents' uneven labor histories and interrupted trajectories of land ownership. His narratives are undoubtedly not as rich in written form as they surely were when they were recounted orally, but they hint at his abilities as a researcher. Here is a glimpse of Salgado's interview with Rogelio Beltrán, in which I have retained the original punctuation and capitalization but expanded the abbreviations:

Arriving at the region of Aguas V[ivas]. i came from San Andres. i arrived at the house of diego castillo. i spent 2 years in that house i didn't have [enough] to buy land. but. a torres family gave me a fanega of land [1.5 acres] and $\mathrm{i}$ built my house. $\mathrm{i}$ lasted 3 years on that land because $\mathrm{i}$ used up the brush $\mathrm{i}$ could clear i sold [it] to mr. Juan Hoyos [illegible word] for $\$ 50$ a hec[tare]. with that base i acquired i bought 2 hec[tares]. it was backed by public lands i started working my piece of land i lived off what i earned from my handicrafts. Jolon, Choco, balai [types of basketry], but, since i did not have seed to sow rice i had to go to Primitivo Lozano for a loan of a puño [a weightmeasure] of rice earning 5 puños but the times were so bad that there was no harvest so i found myself owing 10 puños of rice taking advantage of the opportunity [Lozano] said $i$ had to give him the cost of the 10 puños of rice it's how he got the land two days after i received it he sold it to Euseuio Marines at that time my partner became sick and since pepe [Hoyos?] had taken the land i had to go to him to offer $5 \mathrm{HEC}[$ tares]. and the rest of the farm i sold to Primitivo (CDRBR/M, 0211, fol. 774, pp. 1-2). ${ }^{4}$

Having failed to cobble together a life as a smallholder, Beltrán enlisted as a laborer: "When i lost the farm $\mathrm{i}$ began to work on the farm of Julio Vadel with three children $\mathrm{i}$ lasted 7 years in the time i spent on that farm i received nothing" (p. 4).

Beltrán then goes on to recount how he was cheated out of the fruits of his labor by Badel:

When I retired from the farm I went to Julio Vadel to see if he would pay me my severance and he told me to go to Dr. asa and I sat in his office all day at 3 in the afternoon Dr. Asa called Julio and then he dropped the phone and he told me that I had nothing to claim. and then I left the office and they told me I had to find a lawyer and I went to a lawyer and he got 50 pesos off me to tell me I didn't have a case. (pp. 4-5)

Beltrán's old age was precarious. He opined that the only solution to his problem was social mobilization: “Today I'm old and blind and have nothing. ... And now I'm blind but sure that the program organized by the peasants is good and I ask my son to join it. (pp. 3-4)

Similar tropes appear in Salgado's summary of his interview with Cleto Gómez, another Tuchín peasant who was left in his old age with nothing after working years for the same landowner as Beltrán:

4 Salgado's notes are contained in a notebook that is catalogued as a single folio in Fals Borda's personal archive; for this reason, I also cite the notebook page numbers. 
Deprived of everything without youth now old age was catching up with me, then I lasted 1 year as a worker for. Rafael $\mathrm{H}[\mathrm{oyos}]$. At the end of the year he sold [the farm] to Julio Badel becoming a new owner for whom $\mathrm{i}$, earning by my own hand at first I was the boss in the farm and later oversaw land-clearing I spend most of my time and later ajustero [negotiator] and up in a plot on the same farm that my father-in-law left his daughter, at the time my whole family worked on the farm my wife was a laundress and my sons worked with the horses. And were muleteers my daughters were cooks. nursemaids. and I with old age approaching they looked for a way to force me out of the plot where I lived since the plot was surrounded by the farm they talked my wife into selling the plot, and that destroyed my relations with my wife so today I am alone, I spent 20 years working on the farm I lost everything and they didn't even give me $5 \$$ of severance pay. (pp. 8-11)

Salgado's run-on sentences convey the feeling of a narrator filled with anguish, unburdening his Kaftaesque afflictions on his interviewer, who himself struggled to get the information down on paper. In The Allure of the Archives, Arlette Farge recounts her efforts at making sense of an eighteenth-century document whose contents she could only decipher by reading it aloud. Still, she considers her labor at reading the labyrinthine sentences and making sense of run-on words to be much more than simply a technical challenge faced by the reader of historical documents. Instead, Farge argues that the document opens up an auditory memory and retains "a voice, an intonation, a rhythm" (2015: 61). Certainly, we get the feeling from Salgado's report that we're listening to a Caribbean peasant: we can almost hear his accent and sense the cadence of his speech.

The tropes Salgado employs, and his use of reported speech convey his own means of making sense of the narratives he heard, which he may have jotted down as his interlocutor spoke or, quite possibly, he committed to paper afterwards. All we have are eleven pages out of a tiny notebook, which ended up in Fals Borda's personal archive. I would venture to guess that its contents are a co-construction combining the narrators' accounts with Salgado's interpretation of what he heard, always keeping in mind the fact that writing was a challenge for him and, for this reason, many of the details of the stories, the words and turns of phrases, even the progression of the original narration, were undoubtedly lost. In essence, then, what appears on these pages is as much a product of Salgado's imagination, as it reflects his interlocutors' personal experience.

The narratives by Beltrán and Gómez are visibly consistent. They begin with their migration from the original hamlet of Tuchín to Tuchín de Aguas Vivas. As I will show below when I consider Fals Borda's re-framing of the contents of Salgado's field notes, these landless men from San Andrés de Sotavento arrived in Aguas Vivas in pursuit of plots to till. For these narrators, the search for soil to sustain their families constitutes the backbone of their life stories. Notwithstanding their aspirations, they recall how difficult it was to achieve their shared objective of surviving as smallholders. Beltrán reminiscences about the impossibility of sustaining the finca he painstakingly acquired: he quickly accumulated debt in order to purchase seed but bad weather led to a failed harvest that impeded him from earning what he needed to cover the balance of what he owed, and he was ultimately forced to sell off his land. Gómez was more fortunate, since he had acquired his land by marrying the landowner's daughter-I suspect his father-in-law was also a peasant, but of greater means-but despite this advantage, he was rendered effectively landless when his father-in-law's farm was swallowed up by a large landowner and Gómez was forced to become a salaried worker on his own land. These life histories evince a larger picture in which farms pass through the hands of smallholders into those of more well-off peasants and, eventually, to latifundistas. Once forced into wage labor, the large landowners cheat them out of their wages or their severance pay. Fals' field notes repeat similar experiences in other parts of Córdoba (CDRBR/M, 0247, 0288, 0699), suggesting that these narratives have a great deal in common with those of many Costeño peasants of the period.

While these are common experiences on the Atlantic Coast-migration, land-loss, debt, and exploitative labor arrangements-they also function as narrative strategies governing how elderly male campesinos recounted the most significant events in their lives to a sympathetic interviewer who was also a peasant. 
Italian oral historian Luisa Passerini calls these strategies "highly formalised devices of narration [that] are distinct from the aspects of the life-story which reflect everyday life," that is to say, they are ways of telling stories through a combination of collective memory and individual memory (1987: 19). In other words, these are highly structured narratives. Given that Alfonso Salgado, the interviewer, was a leader of ANUC, the plotting of the life histories he collected was undoubtedly motivated by the political objectives that prompted the interview in the first place: his interlocutors focused on how they lost their land and how latifundistas mistreated them because this information was crucial for the construction of strategies of direct action, such as land occupations. For this reason, these stories replicate the narratives circulated by the peasant organization at cursillos, which the Fundación del Caribe adapted to a comics format more accessible to nonliterate readers (Chalarka, 1985). This conformity is not surprising, given that these elderly men were aware of ANUC's activities; Beltrán says as much at the end of his interview, when he expresses interest in his son joining the organization. 1 will return presently to how Salgado channeled his conversations politically but first, I turn to how Orlando Fals Borda recycled Salgado's notes. This brief digression will allow me to lay out the strategies and philosophy that underlay this process.

\section{Critical Recovery}

Alfonso Salgado's notes furnished raw material that fueled the political aspirations of ANUC, in a process that Fals called "critical recovery" (recuperación crítica). Researchers-who were simultaneously activistswould pay "special attention to those elements or institutions that had been useful, in the past, in confronting the enemies of the exploited classes. Once those elements were identified, one would proceed to reactivating them in order to utilize them in a similar manner in current class struggles" (Bonilla et al., 1972: 51-52). In other words, they would identify political strategies and institutions that could be harnessed to peasant mobilization in the 1970s. An example of critical recovery was the introduction of communal forms of administering lands on haciendas occupied by ANUC; called "baluartes de autogestión campesina" (bastions of peasant self-management), they were modeled after socialist collectives established in the early twentieth century, the most prominent of which was the Baluarte Rojo (the Red Bastion) of Lomagrande, near Montería (Fals Borda, 1986: caps. 5A y 5B). Fals Borda and his co-researchers collected oral histories from the founders of the Baluarte Rojo, combed existing archives, and then introduced the concept to peasant readers through graphic narratives and in cursillos (Chalarka, 1985; Rappaport, 2020: chap. 4), eventually assisting in the founding of baluartes on lands occupied by ANUC. ${ }^{6}$

Fals' field notes constituted a staging-ground on which he could collect and refine his ideas before disseminating them and encouraging ANUC to implement them in practice. Crucial to this project was the creation of a historical narrative explaining the expansion of the hacienda system and the appearance of a landless labor force in the Caribbean region. Salgado's stories furnished valuable primary material to undergird this narrative. Fals reinscribed Salgado's notes - which I discovered in the same file folder that contained Fals'

\footnotetext{
5 I cite here Historia doble de la Costa (Double History of the Coast), Fals' history of capitalist expansion and peasant resistance on the Atlantic Coast of Colombia, which is a two-channeled text, with the left-hand pages telling a history from below (channel A) and the right-hand pages augmenting the narrative with theory, historiography, and methodological discussion (channel B). Hence, each page and chapter is distinguished by the channel to which it belongs.

6 There is no space here to evaluate the success, or lack thereof, of ANUC's baluartes; see Parra Escobar (1983: chap. 10), Rudqvist (1986: chap. 5), and Zamosc (1986b: chap. 8).
} 
own notes and his rewriting of the original interviews by Salgado-emphasizing those details he felt were significant, while leaving out others; he combined them with his own observations in an April 1973 visit that may have coincided with Salgado's. ${ }^{7}$

Fals frequently composed his interpretations in a literary style that foreshadowed his writing in Historia doble de la Costa, the four-volume history he began to publish in the late-197os; his notes evince his search for alternatives to conventional academic prose. It is worth quoting Fals at length:

Around 38 years ago a young Indian called Rogelio Beltrán and his wife arrived in the place that is now called Tuchín. They came from the Tuchín that belonged to San Andrés de Sotavento, in search of lands to work. The situation was very bad in San Andres, where the indigenous reservation was dissolved by act of its Council in the days when General Burgos came in search of oil.

At almost the same time, Alberto Montes and his wife Josefa Choba, also of indigenous descent, arrived.

They settled on public land in the forest, on quite a large expanse, of about 600 hectares. After them other settlers arrived, like Pablo Padilla. Their limits or "marks" were bounded on the side near the sea by more primary forest. This is hilly land, not sought after.... Other settlers looked for flat lands to the south.

They began to clear brush and plant maize, manioc, yams, rice and coffee. They ate pork and game (guartinaja [paca], ñeque [agouti], saíno [collared peccary], armadillo).

A few years later they began to sell "puestos", in other words, cleared lands. Rogelio sold [illegibile word] to Antonio Lozano, who bought by the hectare felled forest or cleared brush. Lozano was from Guamal. He went on buying until his death, after which his son Primitivo followed in his footsteps and ended up buying from Rogelio. The latter was convinced by a son in La Plata (Antioquia) that the farming there was extraordinary, and after the sale he bought a lot in La Plata. There he remained, blind and abandoned by his son after two years, he returned to a plot he still had in Tuchín that now belonged to a son-in-law. There he is today, in that house, blind and alone. The Lozanos are still here, with goo hectares that they accumulated through the purchase of cleared lands from other peasants. They eventually acquired title as occupants of public lands! (CDRBR/M, o210, fols. 768-769)

Fals fleshes out the bare bones of Salgado's diary, explaining why these migrants abandoned San Andrés de Sotavento, which had lost its formal reservation status, exposing its communal lands to land-grabbers. He augments Beltrán's story with the reminiscences of other migrant families and paints a brief but vivid picture of how they lived off these lands day to day. He notes that these were public lands on which landless peasants were free to settle, but documents how the Lozano family bought them up in short order, consolidating 900 hectares and ultimately obtaining title to them, notwithstanding the fact that they had been colonized by campesino migrants. Building on Salgado's notes, Fals emphasizes that the land-poor peasants, who constituted a vulnerable labor pool, were also cheated out of their salaries by well-connected latifundistas:

Julio Badel had violated labor laws when he refused to give severance pay to his workers. He left old Rogelio with nothing although he worked for him for 8 years; blind with cataracts, he left him in Montería to talk with lawyers who made him wait for long hours in their offices. When he went to complain in the Labor office, a telephone call from Badel ensured they would deny him service. (Badel was the secretary of Government of Governor Bula Hoyos [in] 1971.) (CDRBR/M, 0210, fol. 772)

7 Fals inserted a map of Aguas Vivas into his handwritten notes, complete with the names of inhabitants and the latifundia surrounding it (CDRBR/M, 0210, fol. 771). This suggests that in addition to drawing on Salgado's work, Fals met his narrators. 
Fals and Salgado frame their histories differently and their words flow in distinct ways-Fals' graceful prose paints a global portrait in the longue durée while Salgado's rendition of orality adheres closely to the voices he was recording. In this sense, Fals' notes on Rogelio Beltrán and Julio Badel are not raw material, but provisional texts in which he takes a step back from Salgado's observations, recasting his notes as a quasiliterary work. The result is what James Clifford called in his study of French anthropologist Marcel Griaule's field notes a tangle of "various levels of textualization" whose origins are not always transparent (Clifford 1983: 125) - although in this case they are, since we have access to the original fieldnotes.

\section{From Narration to Abstraction: Fals Borda}

As Fals crafted this literary rendition of Salgado's notes, he gathered his thoughts for the ANUC cursillos that the Fundación del Caribe regularly facilitated, which served as the primary conduit by means of which their research would be disseminated, evaluated, and interpreted by peasants. A January 1973 questionnaire presented to the participants at one of these events provides a research guide for would-be peasant researchers. Many of the questions are directed at compiling a general survey of the social and economic conditions of the community, including a history of how local communities were settled, by whom, and how haciendas came to encroach on peasant lands (CDRBR/M, 2187). A series of such leadership workshops gave rise to agrarian history texts that Fals originally published as articles in the leftist magazines Alternativa and Alternativa del Pueblo, and later compiled into didactic textbooks aimed at an advanced peasant leadership (Fals Borda, 1975, 1976). Here, we find Fals' first attempt at presenting peasants with a global vision of how the latifundia expanded, both on the Caribbean Coast and nationally. These texts ultimately made their way, almost as "quotations" from earlier documentation of ANUC's struggle, into Historia doble de la Costa, his agrarian history of the Caribbean Coast, aimed at an academic readership (Rappaport, 2020: chap. 6).

One such cursillo was held in San Onofre, Sucre, in 1973. As Fals explains, "the objective of this project was and is to have trustworthy information at hand about the social and economic development of the Coast, to ideologically and intellectually nourish popular movements, especially the peasant movement, which is the driving force in almost the entire region" (Fals Borda, 1976: 5). The seminar was so successful that Fals was invited to repeat it at the Universidad de Córdoba, resulting in a mimeographed text that was also presented at various academic congresses (1976:6) and which was ultimately published as a cartilla aimed at a peasant readership, Capitalismo, hacienda y poblamiento: Su desarrollo en la Costa Atlántica (Capitalism, Hacienda and Settlement: Its Development on the Atlantic Coast [Fals Borda, 1976]). The text presents a narrative of how the Atlantic Coast was populated, how the hacienda system expanded over the colonial period, and the consequences of the introduction of agrarian capitalism in the nineteenth and early twentieth centuries. Capitalismo presents a regional narrative of economic history, punctuated by examples from across the Coast; it is a revisionist history in which the "progress" and "modernization" achieved by new labor arrangements and the introduction of novel technologies are interpreted as benefitting a capitalist class whose interests are antithetical to those of peasants and proletarians. The text juxtaposes the actions of hacendados and their political enablers with those of peasant organizers; historical vignettes depicting the latter are amplified with the reproduction of key panels from the historical comics that Fals and the Fundación del Caribe produced for ANUC. The text is amply illustrated with photographs and the maps that served as didactic props for the cursillo at which the historical narrative was first aired and analyzed.

The peasant narratives collected by Alfonso Salgado and rendered in literary form by Fals Borda were folded into the broader historical narrative of Capitalismo through a process of abstraction and generalization: 
Notwithstanding the tradition of autonomy and dignity, poor settlers were driven out by the expansion of the haciendas, especially by means of a "law of the three steps" (ley de tres pasos), which continues to structure the appropriation of land and the agricultural surplus. According to this "law" poor settlers clear the brush and undertake all of the tasks of readying the land for production, remaining there for a relatively short time... to move on to clear land in another place (first step). He sells the land cheaply or cedes the improvements he has made to a farmer, contractor or intermediary who semi-exploits the estate and pursues the consolidation or unification of the farms or lots (second step). In turn, this farmer or contractor cedes his rights under pressure from a latifundista bent on expanding his property or creating a new hacienda (third step). The tricks, pressure, demands, swindles and deaths that accompany this "law" have permeated the history of the struggle for land in the entire region. (1976: 41)

Fals goes on to argue that the "law of the three steps explains in good measure the frenzied and violent expansion of the hacienda toward the south and the southwest, particularly during the twentieth century" (1976: 41-42). He identifies the names of the wealthiest landowners in the region, some of them immigrants from France, and other powerful terratenientes from the neighboring department of Antioquia (1976: 42); precisely the enemies ANUC was confronting at the time.

Ultimately, Fals continues, the landless were reduced to eking out a living on small plots provided by the hacendado in exchange for several days a week of labor, sealed by a contract called a "matrícula" (most campesinos could not read the document, nor could they sign their names to it). The matrícula contract was time-limited, but many sharecroppers immediately fell into long-term debt because they could not pay the services of the notary who validated the contract and they ran up bills at the tienda de raya or company store, one of the only places they could cover basic household needs for such staples as sugar, salt, and oil to light their huts. Thus, the matrícula became a kind of bondage, made more bitter by the physical brutality of hacienda foremen and the ubiquitous use of the stocks as a form of torture and public humiliation. The men who told their life stories to Alfonso Salgado were no longer subject to the matrícula—which was abolished in 1921-but their poverty nevertheless forced them to eke out a living as day-workers or sharecroppers, which was itself a kind of bondage.

Fals would insert this narrative into another pamphlet for peasant and proletarian readers, Historia de la cuestión agraria en Colombia (History of the Agrarian Question in Colombia [Fals Borda, 1975: 45-50]) and into the final volume of his four-volume Historia doble de la Costa (Fals Borda, 1986: 113B). This was part of the process that he termed devolución sistemática (systematic devolution), aimed at producing educational materials accessible to readers and listeners with different levels of schooling and political awareness (Fals Borda, 1987: 113). The return of this knowledge in an accessible format, Fals argued, would permit popular organizations to translate history into political action, insofar as the process "complies with the objective set by Italian socialist Antonio Gramsci of transforming 'common' sense into 'good' sense or critical knowledge that would be the sum of experiential and theoretical knowledge" (Fals Borda, 1991: 9). That the process of systematic devolution involved more than simply "returning" information culled from research with peasants is evident in Fals' assertion that the Capitalismo booklet was the product of sustained discussion and debate with peasant activists at various stages of its composition and publication. Of course, the extent to which the narrative ultimately followed Fals' own instincts, as opposed to those of his peasant interlocutors, is up for debate. Zamosc (1986b: 168-172) argues, for example, that ANUC's resignification of the baluarte in the 1970s originated largely in Fals Borda's interpretation of agrarian history, which contended that capitalism developed in local enclaves, later spreading to the entire region; Fals envisioned socialism as following the same path and, correspondingly, expected baluartes to proliferate in the same way. His understanding of historical processes fueled his interpretation of what peasants told him. Ultimately, it was Fals who controlled the writing and publication process. 


\section{From Narration to Persuasion: Salgado}

Alfonso Salgado Martínez was one of a very few peasant leaders affiliated with ANUC in Córdoba who produced educational materials for ANUC's rank and file. It was more common for local and regional ANUC leaders to share their knowledge orally in cursillos than in published form (CDRBR/M, CF, 1391). Salgado describes in the following statement his unusual calling as a researcher and author:

My book, it was a book that was very popular, not only here in Córdoba, but one time when there was a meeting in Palmar de Varela (in the Department of Atlántico) and we went there without money to pay the return fare, imagine: I and other peasant leaders from Córdoba began to sell the pamphlets. And with this book we were able to eat and pay for our return fare, because they saw those pamphlets and they instantly bought them. The book of the Catorce preguntas [Fourteen questions] [was popular] not only here among students but among peasants, because this book is the experience I wrote about... The story of Las catorce preguntas is the unconscious struggle of peasants against landlords and this was understood by peasants. A peasant wrote it. Many peasants said: "Yes, I also did that stuff and I didn't know why I did it." So everyone understood my book perfectly. . . . The book was very useful in orienting peasants. Many peasants have it and keep it. (Parra Escobar, 1983: 146-147)

As I will demonstrate, Salgado's pseudonymously published booklet, 14 preguntas sobre economía política (14 Questions about Political Economy [Martínez 1973]), is quite different from the graphic histories, primers, and magazine articles that emanated from Fals Borda's research group. Many of the Fundación's materials strove to evoke campesino styles of narration, replicating the tone of the conversations that researchers had with narrators: "the work. . . is written to be read aloud; the writing style is similar to the style of the peasants who were interviewed; the language is simple, very typical and a bit literary" (CDRBR/M, 0576, fol. 2764). Salgado's treatise doesn't emulate this language: instead, it originates directly from it. For this reason, his voice differs from that of the Fundación, even if the external researchers' work was accessible to a rural readership. Salgado's pamphlet is more akin to a public address intended to persuade an audience. Far from a written recounting a historical narrative, it is a tool for agitation.

14 preguntas is considerably more polemical than Fals Borda's texts for peasant readers. It does not appear to draw directly on systematic research, but springs from Salgado's personal and political experience; he does not indicate his sources nor, in those instances in which we can identify them, does he dwell on them at length. Instead, his pamphlet is aimed at assisting peasants in developing basic political arguments. Crafted in a question-and-answer format like some traditional school textbooks of the sort that Salgado undoubtedly encountered in his brief time in primary school—and like first-communion manuals—14 preguntas furnishes peasants with answers to what the author imagines are the fundamental questions that grassroots activists might pose to an ANUC organizer: Who benefits from peasant labor? What is the conflict between those who own the means of production and those who do not? How do landlords put their money to work, while peasants must subsist on their own labor? Why do capitalists hire campesinos' daughters as servants? Who is a subversive? Salgado dedicates approximately a page and a half to each of his fourteen questions, supplying his readers with general arguments concerning their worth as human beings. You might say that each of the fourteen questions encapsulates key elements of a grassroots ANUC discourse that translates elementary Marxist arguments into a campesino idiom.

Nonetheless, we can surmise that Salgado drew on some of the experiences he recorded when he met with the rank and file of ANUC. In one question, he asks: "Who is ultimately benefitted by the work of peasants and laborers?" His response: "Most of their work benefits the landlord who, paying miserable wages, enslaves them, so that the landlord becomes well known in the eyes of the industrialists to whom he sells his product as a good farmer (although he has never grasped a machete)" (Martínez, 1973:4). Obviously, Salgado had heard from many of his comrades about their suffering under the rule of large landowners, but he does not offer 
individual examples. Instead, he explains in general terms how peasant labor is transformed into latifundista power when the landowner steps in as the intermediary between the peasant producer and other powerful members of regional society. Similarly, Salgado answers the question "How does the conflict unfold between those who hold the means of production and the dispossessed?" (1973:14-15) by reminding his readers that the struggles of the dispossessed began with the Spanish invasion. He then goes on to cite the early twentiethcentury struggles of peasants in Córdoba, information he may have drawn from one of the Fundación del Caribe's graphic histories (Chalarka 1985:5-25), and invites his readers to join ANUC by reminding them that "for this reason peasants must occupy the lands that are their means of production" (Martínez, 1973: 15).

In one of the questions, there is a brief nod to Salgado's research in Tuchín de Aguas Vivas. He asks, "Why is the industrialist in favor of agrarian reform while the landlord is not?" (1973: 15). Part of his response emphasizes how peasants lost their land: "In the life you lead, if you have a hectare of maize, a profiteer will visit you, offering a little money in advance of the harvest" (1973: 16) — a generic version of the story he painstakingly recorded after conversing with Rogelio Beltrán. Salgado's imaginary landless peasant is hired as a laborer for fifteen pesos a day - in 2021 Colombian currency, approximately 2,000 pesos-a paltry sum that Salgado repeats in response to several of his questions (1973: 19, 21).

Near the end of his treatise, Salgado asks: "The peasant is the pillar of the Republic [El campesino es el sostén de la República]. Why?" He explains that "analyzing the peasant, he is the father of all citizens": he feeds the nation (1973: 22). There is no visual accompaniment to this assertion, only a two-page explanation of how society is propped up by the labor of campesinos, who lose control of the product of their labor as it passes through the hands of intermediaries. However, as I worked through Fals's papers I found the following drawing in a different part of his archive. An unfinished first draft, really, which translates Salgado's text into visual form by mapping out those sectors of society served by campesinos. I don't know who drew the image; perhaps Ulianov Chalarka, the artist whose work is reproduced in the Fundación del Caribe's historical comics. The title of the sketch is in Fals Borda's handwriting; the sociologist also wrote in the top left-hand corner, "version by Alfonso Salgado." At the center is a muscular peasant with the fruits of his agricultural labor on his lap, five lightning-bolts emanating out of his body: an agrarian super-hero. The lightning connects him, in clockwise order, to a uniformed man wearing a helmet and carrying a rifle (labeled "militar"), an older man in profile with glasses with a book suspended in the air in front of him ("intelectual"), an empty box that would eventually be filled with a drawing carrying the label of "obrero" ("worker"), a young man in a jacket carrying a book ("estudiante" or "student"), and a nun with a huge crucifix around her neck ("clero" or "clergy").

I am not aware of the purpose of this image. Perhaps it was intended to be included as an illustration in 14 preguntas, or maybe Salgado planned for it to serve as a prop in study groups where his treatise would be studied (read aloud, so that non-literate peasants, who comprised the vast majority of the peasantry, could benefit from it). Certainly, other popular organizations of the period, including those inspired by La Rosca, used similar props in their adult education programs (Gow, 2010: 198-199). If we combine this draft of a drawing with the text of 14 preguntas, I think we can reflect more deeply on what research meant to peasants.

8 The labels associated with the portraits are in a different hand from Fals'. 


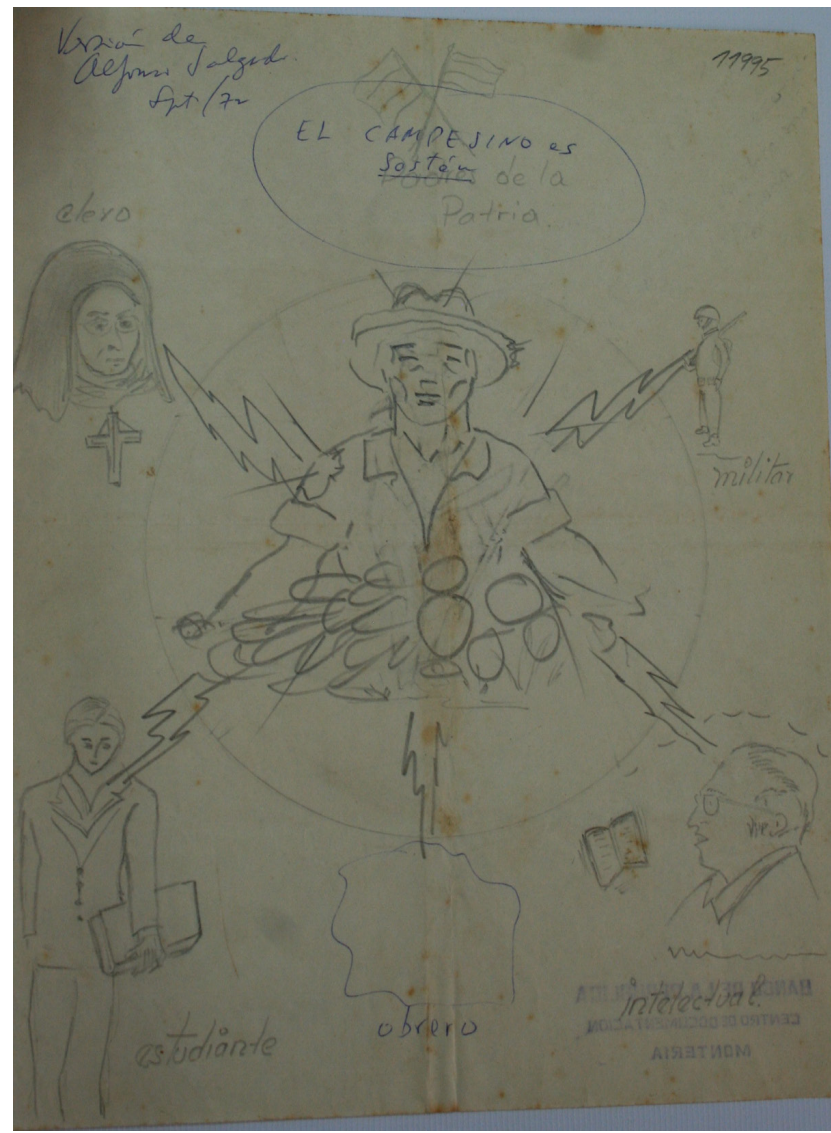

\section{Writing Without Words, Speaking Without Writing}

Although the drawing never came out in print it was obviously connected to the chapter in Alfonso Salgado's booklet. It compresses into a visual image the kinds of connections that he strove to make in 14 preguntas. The sketch originated in the same set of communicative practices that spawned the Fundación's graphic histories: both the comics and this drawing crystallize complex ideas through an appeal to popular culture encoded in visual formats accessible to peasants; moreover, they both place the peasantry at the center of the story. Chalarka did most of the illustrations for the Fundación's publications, so I suspect he was also responsible for the sketch titled "El campesino es el sostén." His graphic histories were the product of rigorous archival and oral historical research, their visual contents captured in sketches that Ulianov Chalarka made as he listened to campesino narrators, something that is evident when his drawings are compared to transcriptions of their taped interviews. Chalarka, like Salgado, was of popular extraction, although with a bit more schooling. His sketches fuse his personal visual memory with popular images from comic-strips and caricatures, observation of peasant lives in the 197os, and the historical photographs that the Fundación made available to him (Rappaport, 2020: chap. 3). In other words, I would venture to guess that Chalarka's intuitive research style echoed in many ways Salgado's, perhaps standing at an intermediate point between campesino notions of research and those of Fals Borda.

For those of us who are academics, research involves a process of collecting, systematizing, and analyzing information culled from interviews, archival and bibliographic materials, quantitative data, and observation. In social science investigations, the research process is commonly controlled by a single researcher or a team of experts. Participatory action research, as it was conceptualized by Orlando Fals Borda, drew on local 
experience to cultivate a philosophy, methodology, and set of techniques for conducting research premised on the establishment of horizontal relationships between external researchers and communities in the service of the organizational objectives of the latter. This implied a very different conceptualization of research from the one conventionally used by academics.

Fals Borda and his colleagues saw participatory action research as a methodology predicated on the insertion of external researchers into social movements (Brandão, 2005). These were not scholars confined to their university desks, but politically committed investigators allied with and participating in the activities of grassroots social movements. Their intention was to conduct research that would generate a knowledge of reality aimed energizing class consciousness and based on a fusion of their own ability to study society and "people's knowledge" derived from the popular classes (Rosca, 1974). In other words, Fals envisioned a dialogue punctuated by activism, with information garnered through research providing the basis for collective decision-making leading to political action (Fals Borda, 1978: 34-35). His methodology was grounded in the conviction that external researchers were not mere observers, nor were the members of popular organizations unsophisticated informants whose words and activities would be recorded by the researcher. As he argues, "one and the other work together, all are thinking and acting subjects in the work of investigation. One would not exploit the other as an 'object' of research, above all because the knowledge is generated and returned in circumstances controlled by the group itself" (Fals Borda, 1987 [1970]: 91). Continuous flows of reciprocity in both research and political action would transform the very meaning of "objectivity" into a bi- or multidirectional process.

Of course, this was aspirational; it was never entirely achieved by the Fundación del Caribe. What it meant in practice was that peasants participated in research, not through the systematic collection of information, but by engaging in co-analysis in workshops in which the protagonists of the struggles of the past told their stories, interpreted the past through re-enactments called sociodramas or through puppetry, and engaged in political debate that fused the interpretation of past experience with the needs of the present. This reconceptualization of the work of investigation redefines collaborative research as a process of collectively or reciprocally thinking through ideas; it does not visualize research as exclusively the systematic collection of data that is then subjected to analysis by external observer to ultimately emerge as a final product (Briones y Ramos, s.f.; Dyrness, 2008: 31; Lawless, 1993; Riaño Alcalá, 2009; Vasco Uribe, 2002: 461).

Alfonso Salgado did produce a final product, but a very different one from Fals Borda and the Fundación del Caribe. His 14 preguntas replicates a lecture that he might have delivered at a cursillo, whose final conclusions are embedded in the drawing titled "El campesino es el sostén," which vividly illustrates the linkages that he saw as sustaining society. The lightning bolts that emanate from the campesino at the center of the image foretell what ANUC's struggle could achieve. This is a speech based on icons and sentiments, rather than data, although it was nourished by research - if we understand research as the assimilation through political action of all the stories and experiences to which Salgado was privy over his life-but it is not research in the same sense that we undertake as academics. Surely, it provoked reminiscences on the part of its readers, many of whom probably listened to the few literates among them read the text aloud. Those sessions, in which peasants pooled their memories, were also a form of research, a space in which narratives were elaborated and interpreted collectively.

Perhaps it is only when we recognize what research means to others, that we will be able to make headway in collaborative research. At some points, the research conducted by campesinos and that of the Fundación intersected, such as when a talented intermediary like Ulianov Chalarka was able to bridge the gulf between them with striking visual materials that captured peasants' imagination at the same time that they were grounded in investigations by trained social scientists. At others, as I have demonstrated in my analysis 
of Alfonso Salgado's 14 preguntas, campesino researchers found their own means of processing what they learned in cursillos, what they heard when they visited communities, and what they remembered from personal experience. The experience of Fals Borda and the Fundación del Caribe does not provide us with all of the answers, but it certainly leads us toward the questions we should ask as we pursue collaborative research strategies.

Received: Juin 25, 2021

Approved: August 09, 2021

\section{Acknowledgments}

My thanks to Les Field and David Gow for their insightful comments on earlier drafts of this paper. Archival research in the Archivo Central e Histórico de la Universidad Nacional de Colombia, Bogotá, and the Centro de Documentación Regional, Banco de la República, Montería, was conducted between 2007 and 2010, with the support of the Graduate School of Georgetown University. I am especially indebted to the directors and staff of the two archives, as well as to Víctor Negrete, one of the founders of the Fundación del Caribe, for his constant support and encouragement. 


\section{References Cited}

\section{Archives}

ACHUNC/B, Archivo Central e Histórico de la Universidad Nacional de Colombia, Bogotá. Fondo Orlando Fals Borda.

CDRBR/M, Centro de Documentación Regional Orlando Fals Borda, Banco de la República, Montería, Córdoba.

\section{Published texts}

BOLAÑOS, Graciela; RAMOS, Abelardo; RAPPAPORT, Joanne and MIÑANA, Carlos. 2004. ¿Qué pasaría si la escuela ...? Treinta años de construcción educativa (with Graciela Bolaños, Abelardo Ramos, and Carlos Miñana). Popayán: Programa de Educación Bilingüe e Intercultural, Consejo Regional Indígena del Cauca.

BONILLA, Víctor Daniel; CASTILLO, Gonzalo; FALS BORDA, Orlando; LIBREROS, Augusto. 1972. Causa popular, ciencia popular: Una metodología del conocimiento científico a través de la acción. Bogotá: La Rosca de Investigación y Acción Social.

BRANDÃO, Carlos Rodrigues. 2005. "Participatory Research and Participation in Research: A Look between Times and Spaces from Latin America”. International Journal of Action Research, 1(1): 43-68.

BRIONES, Claudia; RAMOS, Ana. s.f. "Revitalizing Conversations: Lessons From and About the Production of Intersubjective and Intercultural Knowledge". Canadian Journal of Action Research (in press).

CARO, Catalina; Valencia, Yeromines. 2013. "El caso de pequeñas y medianas minerías en el Cauca: ¿Alternativas o amenazas a la autonomía indígena?” Revista Señas, 2 (Revista de la Casa del Pensamiento de la Çxab Wala Kiwe-ACIN). https:/|www.corporacionensayos.org/revista-senas. Accessed 2 June 2021.

CENTRO POPULAR DE ESTUDIOS. 1972. Manual para cursillos campesinos para cuadros del movimiento campesino. Montería: Centro Popular de Estudios.

. 1974. Nuestra cartilla. Montería: Centro Popular de Estudios.

CLIFFORD, James. 1983. "Power and Dialogue in Ethnography: Marcel Griaule's Initiation". In: George W. Stocking Jr. (ed.), Observers Observed: Essays on Ethnographic Fieldwork. Madison: University of Wisconsin Press. pp. 121-56.

CHALARKA, Ulianov. 1985 [1972-1974]. Historia gráfica de la lucha por la tierra en la Costa Atlántica. Montería: Fundación del Sinú.

DYRNESS, Andrea. 2008. "Research for Change Versus Research as Change: Lessons from a 'Mujerista' Participatory Research Team”. Anthropology \& Education Quarterly, 39(1): 23-44.

FALS BORDA, Orlando. 1975. Historia de la cuestión agraria en Colombia. Bogotá: Publicaciones de La Rosca.

FALS BORDA, Orlando. 1976. Capitalismo, hacienda y poblamiento: Su desarrollo en la Costa Atlántica. Bogotá: Punta de Lanza.

FALS BORDA, Orlando. 1978. El problema de como investigar la realidad para transformarla: Por la praxis. Bogotá: Ediciones Tercer Mundo.

FALS BORDA, Orlando. 1985. Conocimiento y poder popular. Lecciones con campesinos de Nicaragua, México y Colombia. Bogotá: Punta de Lanza/Siglo XXI.

FALS BORDA, Orlando. 1986. Retorno a la tierra: Historia doble de la Costa - 4. Bogotá: Carlos Valencia Editores. FALS BORDA, Orlando. 1987 [1970]. Ciencia propia y colonialismo intelectual: Los nuevos rumbos. Bogotá: Carlos Valencia Editores. 
FALS BORDA, Orlando. 1991. "Some Basic Ingredients”. In: Orlando Fals Borda and Mohammad Anisur Rahman (eds.), Action and Knowledge: Breaking the Monopoly with Participatory Action Research. New York: Apex. pp. 3-12.

FALS BORDA, Orlando. 2007. "La investigación-acción en convergencias disciplinarias". LASA Forum, 38(4): 17-22.

FARGE, Arlette. 2015. The Allure of the Archives. Transl. Thomas Scott-Railton. New Haven: Yale University Press.

GOW, David D. 2010. Replanteando el desarrollo: Modernidad indígena e imaginación moral. Bogotá: Editorial Universidad del Rosario.

LAWLESS, Elaine J. 1993. Holy Women, Wholly Women: Sharing Ministries Through Life Stories and Reciprocal Ethnography. Philadelphia: University of Pennsylvania Press.

MARTÍNEZ, Alsal (Alfonso Salgado Martínez). 1973. 14 preguntas sobre economía política: Textos para cuadros campesinos. Montería: Centro Popular de Estudios.

PARRA ESCOBAR, Ernesto. 1983. La investigación-acción en la Costa Atlántica: Evaluación de La Rosca, 1972-1974. Cali: Fundación para la Comunicación Popular FUNCOP.

PASSERINI, Luisa. 1987. Fascism in Popular Memory: The Cultural Experience of the Turin Workiing Class. Trad. Robert Lumley and Jude Bloomfield. Cambridge: Cambridge University Press/ Paris: Editions de la Maison des Sciences de lHomme.

PEQUÍ, Reinel. 2013. "Guerra, proceso organizativo y juventud indígena”. Revista Señas (Revista de la Casa del Pensamiento de la Çxab Wala Kiwe-ACIN), 2. https://www.corporacionensayos.org/revista-senas. Accessed 2 June 2021.

PÉREZ, Jesús María. 2010. Luchas campesinas y reforma agraria: Memorias de un dirigente de la ANUC en la costa de Caribe. Bogotá: Puntoaparte Editores.

PERNETT, Valentina. 2015. "De cómo Moises Banquett y Orlando Fals Borda hablan de la ANUC". Tabula Rasa, 23: 23-36.

RAPPAPORT, Joanne. 2005a. Intercultural Utopias: Public Intellectuals, Cultural Experimentation, and Ethnic Dialogue in Colombia. Durham: Duke University Press.

RAPPAPORT, Joanne 2005b. Retornando la mirada: una investigación colaborativa interétnica sobre el Cauca a la entrada del milenio. Popayán: Editorial Universidad del Cauca (edited volume).

RAPPAPORT, Joanne. 2015. "La investigación como trabajo de la imaginación”. Revista Señas (Revista de la Casa del Pensamiento de la Çxab Wala Kiwe-ACIN), 4: 117-123.

RAPPAPORT, Joanne. 2020. Cowards Don't Make History: Orlando Fals Borda and the Origins of Participatory Action Research. Durham: Duke University Press.

RIAÑO ALCALÁ, Pilar. 2009. Recordar y narrar el conflicto: Herramientas para reconstruir memoria histórica. Bogotá: Grupo de Memoria Histórica. <www.centrodememoriahistorica.gov.co/index.php/informesgmh/informes-2009/caja-de-herramientas> Accessed 23 June 2012.

ROSCA DE INVESTIGACIÓN Y ACCIÓN SOCIAL. 1974. Manifiesto de la Fundación Rosca de Investigación y Acción Social. Bogotá: Fundación Rosca de Investigación y Acción Social.

RUDQVIST, Anders. 1986. Peasant Struggle and Action Research in Colombia. Uppsala: Research Reports from the Department of Sociology, Uppsala University, vol. 3.

ASCO URIBE, Luis Guillermo. 2002. Entre selva y páramo: Viviendo y pensando la lucha indígena. Bogotá: Instituto Colombiano de Antropología e Historia.

VASCO URIBE, Guillermo; DAGUA HURTADO, Abelino and ARANDA, Misael. 1993. "En el segundo día, la Gente Grande (Numisak) sembró la autoridad y las plantas y, con su jugo, bebió el sentido". In: François Correa (ed.), Encrucijadas de Colombia amerindia. Bogotá: Instituto Colombiano de Antropología. pp. 9-48. 
VELASCO, ROSALBA. 2013. "Un día en el que las mujeres indígenas nos reunimos a tejer la memoria y la palabra”. Revista Señas (Revista de la Casa del Pensamiento de la Çxab Wala Kiwe-ACIN), 2. https:/|www. corporacionensayos.org/revista-senas. Accessed 2 June 2021.

ZAMOSC, León. 1986a. "Campesinos y sociólogos: reflexiones sobre dos experiencias de investigación activa en Colombia”. In: Orlando Fals Borda et al., IAP en Colombia: Taller Nacional, Bogotá, noviembre 14 al 16 de 1985, 19-42. Bogotá: Punta de Lanza/Foro Nacional por Colombia.

ZAMOSC, León. 1986b. La cuestión agraria y el movimiento campesino en Colombia: Luchas de la Asociación Nacional de Usuarios Campesinos (ANUC), 1967-1981. Bogotá: Instituto de Investigación de las Naciones Unidas para el Desarrollo Social/Cinep.

Joanne Rappaport

Georgetown University

Department of Spanish and Portuguese

Washington DC

https://orcid.org/o0oo-0002-7602-7117

Email: rappapoj@georgetown.edu 